\title{
JUURNAL_RU
}

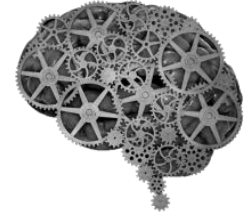

COMPANY GROUP "INTELLEKT"

\author{
Татьянина Л.Г. \\ Удмуртский государственный университет \\ Ижевск, Россия
}

doi: 10.18411/lj2016-3-79

\section{Использование технических средств при проведении допроса: дискуссионные вопросы}

Необходимость сохранения показаний, полученных во время допроса в ходе предварительного расследования, обуславливает использования технических средств при его проведении. Безусловно, что записывать показания, получаемые при производстве любого допроса, представляется нецелесообразным. Следует использовать видеозапись или звукозапись тех показаний, которые позволяют получить информацию, имеющую значение для производства по уголовному делу при необходимости их сохранения.

Сохранение первоначальных показаний с использованием технических средств обусловлено следующими факторами. Сроки производства по уголовным делам, несмотря на их установление в УПК РФ фактически не имеют границ. Участники процесса, давая показания в судебном заседании через несколько лет после совершения преступления, с трудом могут вспомнить обстоятельства произошедшего. Протокол допроса, который содержит показания лица, которые были даны в процессе предварительного расследования, не может заменить живых показаний, поскольку информация в нем отражается следователем с учетом его субъективного изложения показаний. Наличие- звуко или видеозаписи показаний позволяет объективно оценить их после прослушивания. 
Уголовное судопроизводство осуществляется при противодействии процессу предварительного расследования и судебного разбирательства. В этой связи целесообразно произвести допрос потерпевших и свидетелей с применением звуко- или видеозаписи, чтобы сохранить их первоначальные показания. При изменении показаний потерпевшим или свидетелем прослушанная запись их показаний не позволит заявить о том, что они были неправильно изложены в протоколе. Наличие звуко- или видеозаписи позволит провести судебно-психологические экспертизы, связанные с определением психологического состояния во время дачи показаний. Необходимо учитывать и тот факт, что потерпевший или свидетель могут изменить место жительства, заболеть и т.п., в указанных случаях наличие звуко- или видеозаписи показаний позволит более объективно оценить их показания. В случаях, когда в качестве свидетеля или потерпевшего выступает долгожитель, его показания следует записывать с использованием видеозаписи. Наличие видеозаписи позволит оценить состояние лица, дающего показания, при необходимости использовать ее при производстве экспертизы.

При производстве по уголовным делам в качестве потерпевших очень часто выступают малолетние (несовершеннолетние в возрасте до 14 лет) дети. Любая беседа с ребенком относительно произошедших с ним событий наносит ему огромную психологическую, часто психическую травму, поэтому следует как можно осторожнее проводить допрос малолетнего потерпевшего. Необходимо учитывать, что ребенок после совершения в отношении него преступления подвергается реабилитации, направленной на сглаживание и устранение негативной информации из его памяти. В целях максимального сохранения информации от ребенка целесообразно использование видеозаписи его допроса. В последующем ее можно использовать при необходимости и для производства судебно-психологической экспертизы. Видеозапись показаний несовершеннолетнего позволит исключить его вызов в судебное заседание или поставить под сомнение его первоначальные показания. 
Решение вопроса о проведении допрос подозреваемых с использованием видеозаписи осуществляется индивидуально в каждом конкретном случае следователем или дознавателем. Безусловно, что видеозапись допроса подозреваемого должна осуществляться в случае, когда его личность не установлена, либо установлена на основании его собственных показаний. Целесообразно проводить допрос подозреваемого с использованием видеозаписи по делам об особо тяжких преступлениях, поскольку необходимо зафиксировать не только его показания, но и психологическое состояние. Звуко- и видеозапись последующих показаний уже фиксирует относительно обдуманную и подготовленную информацию, продуманный стиль поведения.

Допрос обвиняемого с использованием звуко- видеозаписи целесообразен, когда обвиняемый дает развернутые показания по предъявленному обвинению. В остальных случаях применение технических средств при допросе обвиняемого решается в индивидуальном порядке.

Применение звуко- видеозаписи показаний целесообразно при допросе лиц, не владеющих языком судопроизводства. Данное положение обусловлено следующими моментами. В Российской Федерации, несмотря на многонациональное население страны и возможность осуществлять судопроизводство на национальных языках субъектов Российской Федерации, отсутствуют юридические словари с русского языка на национальные языки народов, проживающих на территории России, в связи с чем юридический перевод осуществляется лицом, владеющим национальным языком, но не знающим тонкостей юридического перевода, особенностей и значений терминов, поэтому возникает возможность неточного перевода, искажающего смысл сказанного. Наличие звуко- или видеозаписи показаний позволит проверить качество перевода при возникновении спорной ситуации.

Невозможно однозначно решать вопрос о применении звуко- или видеозапись при производстве допроса в связи с тем, что допрашиваемое лицо может отказаться от использования технических средств, ему можно разъяснить 
цели их применения, гарантии конфиденциальности, защиты прав лица, но если оно не согласиться давать показания, то принудить его будет невозможно. Негласное использование технических средств при производстве допроса недопустимо. Всегда следует предварительно подготовить допрашиваемое лицо для того, чтобы оно согласилось на дачу показаний с использованием звуко- или видеозаписи. Указанные предложения позволят обеспечить сохранность полученной при допросе информации и обеспечить ее качество. 